\title{
Changxing $\mathrm{Li}$
}

\section{Introduction}

Innovation has received more and more attention in the European Union since adoption of the Lisbon Strategy in 2000. In 2010 the European Commission 2010; European Council adopted a new strategy, Europe 2020, which stressed again the importance of innovations. Therefore it is important to evaluate the current level of the European Union Member States' technological and economic development as well as its innovations impact on it. Innovation impact on economic development was analyzed by correlating various composite indices with GDP per capita indicator (Fagerberg \& Srholec, 2008). The author proposes a conceptual model for economic development evaluation according to a world-system approach. The level of economic development can thus be identified by a system of indicators rather than single one (e.g. GDP per capita).

Wallerstein suggested this world-system approach $(1974 ; 1979)$. This theory explains structure, relations and dynamics of international systems encompassing separate entities such as states (Chase-Dunn, 1979; Shannon, 1996). After Shannon (1996), ChaseDunn, Durkheim and others made the most important contributions to the development of the theory. The world-system perspective integrates all branches of social sciences, such as sociology, political and economic sciences. Therefore the system can be understood as a set of changing economic, political and social relations. Recently, the world-system theory was applied in such areas as ecology (Moore, 2003). This study mainly focuses on the economic aspects of world-system relations. However, several additional dimensions can be outlined when analyzing patterns of relations among members of the world-system, such as international trade, diplomatic ties, arms trade and military interventions (Rossem, 1996, p. 513). Furthermore, this research is restricted to Member States of the European Union.

Links between innovations, competitiveness and development have been analyzed in many studies recently (Fagerberg \& Srholec, 2008; Huggins \& Izushi, 2009; Sabadie \& Johansen, 2010; Liagouras, 2010; Ahmed et al., 2018). Although political, economic and social integration of the Europe has been continuing for more than 50 years, economic development of the European countries is still uneven (de Arriba Bueno, 2010; Yan et al., 2017). Therefore, it can be predicted that different European Union Member States performs different roles in the European world-system as well as in the global world-system. The aim of this article is to propose additional model for identification of state's role in the world-system. In order to achieve the aim the following tasks were raised: 1) to overview world-system approach; 2) to define system of indicators, identifying roles of states in the world-system; 3) to apply multicriteria evaluation methods and thus classify European Union Member States into relevant groups of world-system participants. The article is hence organized into respective sections.

The data from 27 Member States of the European Union is analyzed in this study. The data was obtained from World Development Indicators, Statistics Iceland and EUROSTAT databases. Period of the investigation covers year 2008. Methods of multi-criteria evaluation, namely MULTIMOORA and TOPSIS, were used to summarize and interpret the data. 


\section{Theoretical Fundaments of World- System Approach}

The author of world-system approach Wallerstein argued that this system expanded during sixteenth century in Europe and Latin America due to Great Geographic Discoveries and colonization processes (Wallerstein, 1974; Chase-Dunn, 1979; Shannon, 1996). This system became global one in the late nineteenth century when all remaining parts of the world were incorporated into. Thus, the term "world" in this context should not be understood as geographic definition "globe", but rather than boundaries of the existing system of division of labour (ChaseDunn, 1979). Wallerstein (2004) argued that term "world-system" refers to system that is a world itself. These boundaries separate participants of the world-system according to two dimensions: hierarchical and territorial. Therefore high-wage goods producing core of the system and lowwage goods producing periphery can be defined. Core states export high-technology goods and import less technologically advanced production from core countries, thus accumulating capital from peripheral states (Fig. 1). Expansion (as well as deepening) processes of the system do not change this pattern of the system, but particular forms of hierarchical organization are replaced by new ones (e.g., feudal serfdom in periphery nowadays are virtually eradicated, but less obvious forms of slavery still exist in these areas). In addition, these processes allow upward (from the periphery of the world-system) and downward mobility of states (Chase-Dunn, 1979, p. 602).

The core states possess the largest part of world's economic, technological and military resources. Therefore such states dominate international politics. United States, United Kingdom, Germany and France can were classified as core states at the very end of the $20^{\text {th }}$ century. In addition a group of states, namely Canada, Sweden, Norway, Finland, Belgium, Austria, Italy, Japan and Australia, was described as minor core powers (Shannon, 1996). Since the most advanced forms of industrial production are to be found in the core states, the highest per capita income and the highest increases in per capita wealth are also observed here. Such mass-manufacturing industries as steel, autos, textiles etc. has been transferred from core to (semi)periphery while high-tech manufacture of electronics and other newer industries are getting more importance in the core. Thus the core states specialize in the most technologically advanced, capitalintensive and high-wage production (Shannon, 1996). Furthermore, proportion of white-collar workers in the labour force increased thus increasing the size of the middle class and reducing inequality of income and wealth.

\section{Fig. 1: Relations pattern of the world-system}

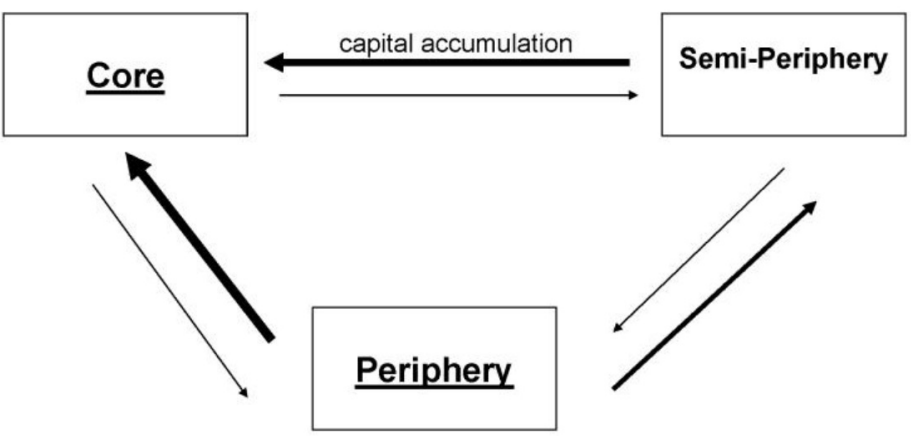


Opposite characteristics can be attributed to peripheral states. Sub-Saharan states in Africa and many Asian states can be considered as peripheral states (Shannon, 1996). The periphery is primary location of low-wage production, coercive labour and exploitation: International Labour Organization estimated that more than 87 per cent of minimum 12.3 million victims of coercion were employed in developing countries of Asia and Latin America (Belser et al., 2005). In addition, peripheral states exchange their low-wage production into high-wage core production, therefore core states obtain value-add created in the periphery. Export of raw materials and agricultural production remains one of the main attribute of peripheral participation in the worldeconomy. Thus, relatively more labour force is employed in agriculture. However, demand and prices for these commodities remain uneven and varying significantly. Labour intensive (low-wage) goods, namely textiles, apparel etc., comprises the large part of exports. Industrialization remained limited compared to that in the core states. Many industrial facilities were financed by core countries and corporations. Rapid industrialization was observed in peripheral states. Furthermore, and these states still remain the primary location for future growth of urban population while rural growth will be subdued (Montgomery, 2008). Most of urban dwellers are employed in informal sector. Peripheral countries are economically underdeveloped thus their per capita GNP is relatively low and sufficient growth in per capita GNP is observed only in small states.

The semi-periphery consists of states that are more developed than peripheral, but underdeveloped in comparison with core states. As number of peripheral countries has decreased from the beginning of the $20^{\text {th }}$ century the semi-periphery remains the largest group of states. Semi-peripheral states function as regional powers in their regions. Since the semi-periphery has experienced industrialization, per capita GNP growth is similar to that of core states while per capita GNP remains lower. Semi-peripheral countries, that have successfully performed domestic accumulation of capital (e.g. South Korea, Taiwan, Singapore), avoided so called debt peonage (i.e. external debts). However, exports of peripheral-like products remain significant alongside with exports of more sophisticated production. Due to lower labour costs, new semi-peripheral industries are those declining in the core. In addition, rural population is smaller than in periphery. Moreover, significant

\section{Fig. 2: Characteristics of production and labour in different world-system areas}

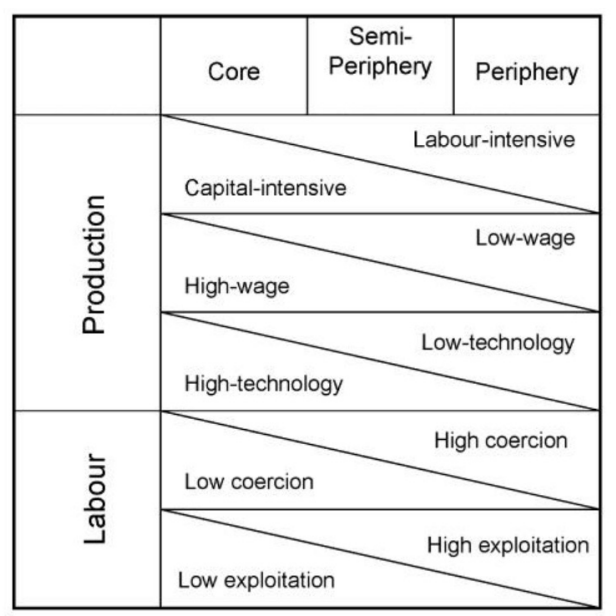


part of urban labour force is employed in informal sector (Maloney, 2004). However, the middle class is larger than in periphery (Ravallion, 2010). All the above characteristics are summarized in Fig. 2.

Such pattern of inter-state relations is dynamic: states can either ascend or descend in the world-system. For example, marine states, namely United Kingdom, Holland, Spain etc., were the main core powers during $16^{\text {th }}-18^{\text {th }}$ centuries, but only United Kingdom remained in the core while others descended in the world-system (Chase-Dunn, 1979). United States ascended in the world system during the $20^{\text {th }}$ century (Shannon, 1996). After the end of the Cold War former socialist states mainly ascended in the world-system and became semi-peripheral (Shannon, 1996; Lane, 2006). China can be presented as yet another case of country moving from periphery to core due to international trade flows, capital accumulation and influence in the international politics (Ma et al., 2017; Li et al., 2017; Zhu et al., 2017). Significant innovations have been achieved in the Central and Eastern European countries due to integration in the European Union (Su et al., 2018; Baležentis et al., 2017).

By creating world-system approach, Wallerstein integrated dependency theory, capitalism, imperialism and state system. Thereafter a world-system is defined as "any effective division of labour ..., which encompasses more than one cultural system" (Chase-Dunn, 1979, p. 603). World-systems can be divided into two types: world-empires, where territorial division of labour is controlled by single administrative centre (e.g., the Roman Empire); and world-economies, where the division of labour is organized by political means among many unequal and competing states. In addition, those member states of the world-system usually represent interest of classes which possess control of these states. Thus in the long run world-system becomes arena for inter- and intraclass competition and is not controlled by any single state, since no world-state exists.

Chase-Dunn (1979) outlined descriptive schema explaining changes of the worldsystem in time. This schema consists of three main components: constants, cycles and trends. Three constants can be defined: 1) commodity production; 2) the core-periphery division of labour and forms as well as means of labour control; 3) the state system with relatively strong core states and relatively weak periphery states. Three cycles repeat themselves periodically in the world-system. The first cycle describes general economic activity and rate of capital accumulation. Such cycles were called Kondratieff waves (Schumpeter, 1939). The second cycle describes relations between core countries and ranges between multicentrity (i.e. single state controls the system) and unicentrity in areas of military and economic competition.

\section{Fig. 3: Conceptual model for identification of states' roles in the world-system}

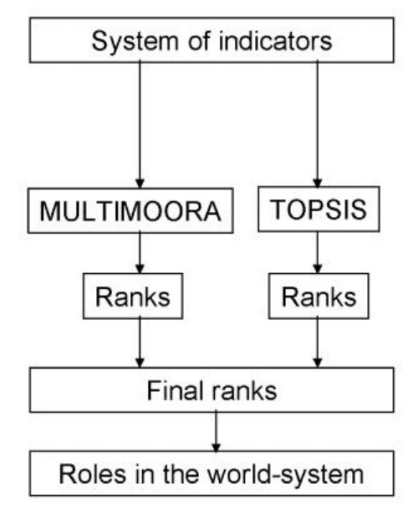


In the third cycle, periods of relatively free international trade are replaced by periods of politically controlled trade. Finally there were four trends outlined: 1) the expansion of the world-system into new areas; 2) improving commodity relations; 3) state formation states are getting more power and control of areas and citizens; 4) concentration of capital (i.e. increasing impact of enterprises).

In network analysis, roles can be defined as abstract systems of relationships among positions (Rossem, 1996, p. 509). On the other hand, positions are concrete and assigned to specific segment. Actors in different positions can act with similar roles, but not vice versa.

\section{Analysis of the European Union Economic Development}

The conceptual model for assessment of European Union Member States' technical and economic development and thus their roles in the European world-system is presented in this section (Fig. 3). It will therefore be divided into three respective parts: for defining the system of indicators; for overviewing and choosing multi-criteria evaluation methods; and for final identification of roles of the European Union Member States.

\subsection{Multi-Criteria Evaluation Methods}

Application of multi-criteria evaluation methods is explored in branch of decision making theory (Zeng et al., 2018; Zeng \& Xiao, 2018; Zhou et al., 2018; Chen et al., 2018). There are many multiple criteria decision making methods developed.

Technique for the Order Preference by Similarity to Ideal Solution (TOPSIS) was introduced by Hwang and Yoon (1981). MultiObjective Optimization by ratio Analysis (MOORA) method was offered by Brauers and Zavadskas (2006) on the basis of previous researches (Brauers, 2004). This method was further developed (Brauers \& Zavadskas, 2010) and became MULTIMOORA (MOORA plus the full multiplicative form). Numerous examples of application of these methods are present (Brauers et al., 2007; Brauers \& Ginevičius, 2009; Brauers \& Zavadskas, 2009; Brauers \& Ginevičius, 2010).

Weighting of objectives has crucial importance in multi-criteria evaluation methods. Churchman, Ackoff and Arnoff (1957, p. 151) see two phases in weighting the objectives:
1. Normalization of values for each of the objectives, which corresponds to the general meaning of normalization: "Normalization means reduction to a normal or standard state (US Webster Dictionary). However, the term got many interpretations in many fields such as in international politics and in technology. In the last case the stress in mainly put on the unification of diverting systems of measurement. As decision making is interested in measurement, normalization in technology is a main starting point, beside normalization in money terms and in dimensionless measures" (Brauers, 2007, p. 445).

2. Voting on importance of each objective $j$ in an executive committee with $\sum_{j=1}^{n} w_{j}=1$.

Hwang and Yoon (1981, p. 99) take this concept over in what they call SAW (Simple Additive Weighting method): usually the weights are normalized so that $\sum_{j=1}^{n} w_{j}=1$.

Kettani et al. (2004) stress also the duality of the weighting problem. Churchman et al. (1957, p. 139) indicated already the need of dimensionless measures by the formula: $x_{i j}^{\prime *}=x_{i j} / \sum_{i=1}^{m} x_{i j}$, which would make outside normalization unnecessary.

Going out from the raw data a response matrix is composed with the objectives (criteria) as columns and the alternative solutions as rows. The problem of duality of the weights is posed by reading the matrix horizontally and not vertically. This vertically reading as applied in MULTIMOORA and TOPSIS realize dimensionless measures making external normalization unnecessary.

Therefore convergence of opinion between all stakeholders interested in the issue is reached by a Delphi technique. In this way as the objectives are quantified convergence of opinion to be reached concerning significance coefficients is not difficult. To know who the stakeholders are and to bring them together are more difficult problems. However successful applications can be found (Brauers, 2002). More specification is brought by replacing significance coefficients by sub-objectives, e.g., 3 sub-objectives replace one objective and the significance coefficient of three.

MULTIMOORA and TOPSIS methods will be used in this study. All the objectives will have 
the same importance with uniform significance coefficients.

\section{1) The MULTIMOORA method}

The MOORA method was developed by Brauers and Zavadskas (2006). The initial step of MOORA method is construction of matrix $X$ with its elements $x_{i j}$ corresponding to the $i$-th alternative of $j$-th objective $(i=1,2, \ldots, m$ and $j=1,2, \ldots, n)$. In this case we have $n=7$ objectives - indicators - and $m=27$ alternatives - European Union Member States. MOORA method comprises the two approaches, namely the ratio system and the reference point approach.

The Ratio System of MOORA. Ratio system embarks on the data normalization via comparison of each alternative against the aggregate one:

$$
x_{i j}^{*}=\frac{x_{i j}}{\sqrt{\sum_{i=1}^{m} x_{i j}^{2}}},
$$

where $x_{i j}^{*}$ represents the $i$-th alternative of $j$-th objective (in this case $-j$-th structural indicator of $i$-th country). In general case, the normalized values fall within the interval $[-1 ; 1]$. The procedures for normalization in the context of decision making were analysed in a more detailed manner in the study by Brauers (2007). The normalized values are further aggregated for each alternative. Specifically, they are added up (in the case of benefit indicators which are to be maximized) or subtracted (in the case of the cost indicators which are minimized), thus obtaining the summarizing indicator representing the utility of a certain alternative as follows:

$$
y_{i}^{*}=\sum_{j=1}^{g} x_{i j}^{*}-\sum_{j=g+1}^{n} x_{i j}^{*},
$$

where $g=1, \ldots, n$ represents the number of objectives to be maximized (benefit criteria). The alternatives are ranked on the basis of the resulting indicator by assigning higher ranks for alternatives with higher values of $\mathrm{y}_{\mathrm{i}}^{*}$.

The Reference Point of MOORA. Reference point approach applies the results obtained in the ratio system. Specifically, the yardstick alternative is defined as the Maximal Objective Reference Point (vector). The coordinates of this point are the ratios found in formula (1). The $j$-th coordinate of the reference point is given by maximum over the alternatives $r_{j}=\max _{i} x_{i j}^{*}$ in case of benefit criteria (minima are considered for the cost criteria). Therefore, one uses the maxima or minima associated with the objectives (structural indicators) when defining the reference point. Subsequently, Then every element of normalized responses matrix is recalculated and final rank is given according to deviation from the reference point and the Min-Max Metric of Tchebycheff:

$$
\min _{i}\left(\max _{j}\left|r_{j}-x_{i j}^{*}\right|\right) .
$$

The Full Multiplicative Form and MULTIMOORA. Brauers and Zavadskas (2010, p. 13-14) introduced an extension of the MOORA technique, namely the Full Multiplicative Form which relies on the multiplicative utility function. The utility of each alternative is obtained by considering the products of the criteria. For the $i$-th alternative, we have:

$$
U_{i}^{\prime}=\frac{A_{i}}{B_{i}}
$$

where $A_{i}=\prod_{j=1}^{g} x_{i j}, i=1,2, \ldots, m$ stands for the product of benefit criterion values for the $i$-th alternative with $g=1, \ldots, n$ denoting the number of criteria (structural indicators) to be maximized and where $B_{i}=\prod_{j=g+1}^{n} x_{i j}$ stands for the product of cost criterion values of the $i$-th alternative with $n-g$ being the number of criteria (indicators) to be minimized. Thus MULTIMOORA treats MOORA(i.e. Ratio System and Reference point) and the Full Multiplicative Form as the equally important measures of the utility. Ameliorated Nominal Group and Delphi techniques can also be used to reduce remaining subjectivity (Brauers \& Zavadskas, 2010, p. 17-19).

\section{2) The TOPSIS method}

The algorithm of TOPSIS method is presented according to Hwang and Yoon (1981). Initially response matrix $X$ is normalized and thus dimensionless criteria obtained:

$$
a_{i j}=\frac{x_{i j}}{\sqrt{\sum_{i=1}^{m} x_{i j}^{2}}},
$$


where $a_{i j}$ is the normalized value for $i=1,2, \ldots, m$ and $j=1,2, \ldots, n$. It is obvious that $a_{i j}=x_{i j}^{*}$. The weighted normalized values of criteria $v_{i j}$ are calculated as follows:

$$
v_{i j}=q_{j} a_{i j},
$$

with $q_{j}$ being significance coefficient of the $j$-th criterion; $i=1,2, \ldots, m$ and $j=1,2, \ldots, n$. Positiveideal and negative-ideal solutions denoted respectively as $A^{*}$ and $A^{-}$are identified in the following way:

$$
\begin{aligned}
& A^{*}=\left\{\left(\max _{i} v_{i j} \mid j \in I\right),\left(\min _{i} v_{i j} \mid j \in I^{\prime}\right),\right. \\
& i=1,2, \ldots, m\}=\left\{v_{1}^{*}, v_{2}^{*}, \ldots, v_{m}^{*}\right\}, \\
& A^{-}=\left\{\left(\min _{i} v_{i j} \mid j \in I\right),\left(\max _{i} v_{i j} \mid j \in I^{\prime}\right),\right. \\
& i=1,2, \ldots, m\}=\left\{v_{1}^{-}, v_{2}^{-}, \ldots, v_{m}^{-}\right\},
\end{aligned}
$$

where $I=\{1=1,2, \ldots, m\}$ and $\mathrm{j}$ are associated with the benefit criteria, $I^{\prime}=\{j=1,2, \ldots, n\}$ and $j$ are associated with the loss criteria. The $n$-dimensional Euclidean distance method is then applied to measure the distances of each alternative from the positive-ideal solution and the negative-ideal solution:

$$
\begin{aligned}
& S_{i}^{*}=\sqrt{\sum_{j=1}^{n}\left(v_{i j}-v_{j}^{*}\right)^{2}}, \\
& \text { for } i=1=1,2, \ldots, m \\
& S_{i}^{-}=\sqrt{\sum_{j=1}^{n}\left(v_{i j}-v_{j}^{-}\right)^{2}},
\end{aligned}
$$

for $i=1,2, \ldots, m$,

with $v_{j}^{*}$ and $v_{j}^{-}$being obtained from formulas (7) and (8) respectively. Finally, the relative similarity to the positive-ideal solution is calculated (proximity to positive and remoteness to negative values):

$$
C_{i}=\frac{S_{j}^{-}}{S_{j}^{*}+S_{j}^{-}},
$$

where $C_{i} \in[0 ; 1]$ with $i=1,2, \ldots, m$. The best alternative can therefore be found according to the preference order of $C_{i}$.

\subsection{System of Indicators}

The system of indicators was used to identify the role of each European Union Member State. The system of indicators was developed according to theoretical fundaments of the world-system. The set therefore included main factors influencing mode of production and labour conditions (as shown in Fig. 2). Tab. 1 summarizes information about the indicators, identifying core state. Data from World Development Indicators (World Bank), EUROSTAT and Statistics Iceland databases covering year 2008 was used in the analysis.

Gross national income (GNI) per capita based on purchasing power parity (PPP) is GNI translated to international dollars based on the underlying rate of purchasing power parity. The concept of the international dollar allows for establishing artificial currency of the same purchasing power over GNI as a US dollar has in the United States. The very GNI is obtained as the aggregate of value added generated by all resident producers plus any product taxes (less subsidies) not included in the valuation of output plus net receipts of primary income (compensation of employees and property income) from abroad. Annual earnings indicator enables to identify whether $\mathrm{GNI}$ is invested in manufacturing and thus redistributed as wages, salaries etc. High values of GNI per capita and annual earnings are common to core states. High-technology exports are products with high R\&D intensity, such as aerospace equipment, computers, pharmaceuticals, scientific instruments, and electrical machinery. As mentioned before, core countries tend to have greater volumes of hightechnology exports. Share of extra-EU exports is expressed as percentage of total extra-EU export and hence enables to identify countries depending to the core of European as well as global world-system. Higher values of such indicator thereof reflect specific state's impact on the European Union economy as a whole. Employment in agriculture is expressed as percentage of total employment. Low values of this indicator should be observed in the core countries since their economies need to be oriented towards production of high-technology commodities. Growing urban populations' 
Tab. 1: System of indicators used for evaluating the European Union Member States

\begin{tabular}{c|l|c|c} 
No. & \multicolumn{1}{|c|}{ Indicator } & Unit of measurement & Desirable value \\
\hline 1. & GNI per capita & PPP & Max \\
\hline 2. & Annual earnings & EUR & Max \\
\hline 3. & High-technology exports & Per cent & Max \\
\hline 4. & Share of extra-EU exports & Per cent & Max \\
\hline 5. & Employment in agriculture & Per cent & Min \\
\hline 6. & Urban population & Per cent & Max \\
\hline 7. & Unemployment & Per cent & Min \\
\hline
\end{tabular}

Source: designed by the author

share in total national population is also a result of economic transition. Successful core states should employ as much labour force as possible in order to improve their production capabilities. On the other hand, higher rates of unemployment may lead to some sorts of coercion, expansion of informal sector and other peripheral peculiarities. Furthermore, some studies (Korpysa, 2010) argue that higher rates of unemployment suppress entrepreneurship abilities of the population. The resulting decision matrix is presented in Tab. 2 .

\subsection{Assessment of the Financial and Economic Development}

Results of MULTIMOORA and TOPSIS methods are summarized in Tab. 3. Data analysis began with application of the MOORA method (the data are available from the author upon request). First of all, initial data were normalized according to formula (1). Then formula (2) was applied ant Ratio System ranks therefore obtained. Next step included identification of the co-ordinates of the reference point and application of formula (3) in order to compute deviations from the reference point with respective ranks for each Member State. The Full Multiplicative Form method was used by applying formula (4) on initial data. Finally, ranks of MULTIMOORA were calculated by minimizing sum of ranks, obtained by methods of Ratio System, Reference Point and Full Multiplicative Form. Final ranks obtained by MULTIMOORA are presented in Tab. 3.

The TOPSIS was implemented as follows: Since all the objectives have the same importance, uniform significance coefficients $q_{j}=1 / n$ were obtained, with $n$ being number of indicators. Normalized data were therefore weighted according to formula (6). Positiveideal and negative-ideal solutions were then identified according to formulas (7) and (8) respectively. Squared distances from ideal solutions and similarities to them of each Member State were calculated using formula (9) and formula (10). The analysis ended up by applying formula (11) and thus obtaining ranks by TOPSIS method (Tab. 3).

Final ranks in Tab. 2 were obtained by minimizing sum of ranks from the two latter methods. All Member States were assigned either of three roles in the European worldsystem. Best performing states with ranks from 1 to 9 were considered as core states, those possessing ranks $10-18$ - as semiperipheral states, and those with ranks 19-27 - as peripheral states. It should be noted that all European states are unequivocally semiperipheral at least in the global world-system, thus their roles of peripheral states are only valid in the context of the European worldsystem.

The most significant differences between ranks provided by MULTIMOORA and TOPSIS were observed between those of small states, namely Cyprus, Luxembourg and Malta. These states sometimes are omitted from analysis because of extremely high values of certain indicators. However, application of two different multi-criteria evaluation methods improved robustness of the results.

According, to the final ranking, core of the European world-system consists of Germany, United Kingdom, France, the Netherlands, Italy, Belgium, Ireland, Denmark and Sweden. The results also suggest Luxembourg, Austria, 


\section{Tab. 2: Decision matrix}

\begin{tabular}{|c|c|c|c|c|c|c|c|}
\hline Member State & $\begin{array}{c}\text { GNI per capita, } \\
\text { PPP } \\
\text { (current inter- } \\
\text { national \$) }\end{array}$ & $\begin{array}{l}\text { Average } \\
\text { annual } \\
\text { earnings, } \\
\text { EUR }\end{array}$ & $\begin{array}{l}\text { High-technolo- } \\
\text { gy exports } \\
\text { (\% of ma- } \\
\text { nufactured } \\
\text { exports) }\end{array}$ & \begin{tabular}{|c|}
$\begin{array}{c}\text { Share of } \\
\text { extra-EU } \\
\text { exports (\% } \\
\text { of total extra- } \\
\text {-EU export) }\end{array}$ \\
\end{tabular} & \begin{tabular}{|c|} 
Employment \\
in agriculture \\
(\% of total \\
employment)
\end{tabular} & $\begin{array}{c}\text { Urban } \\
\text { population } \\
\text { (\% of total) }\end{array}$ & $\begin{array}{l}\text { Unemploy- } \\
\text { ment, total } \\
\text { (\% of total } \\
\text { labor force) }\end{array}$ \\
\hline \multirow{2}{*}{$\begin{array}{l}\text { Direction of } \\
\text { optimization }\end{array}$} & MAX & MAX & MAX & MAX & MIN & MAX & MIN \\
\hline & 1. & 2. & 3. & 4. & 5. & 6. & 7. \\
\hline Belgium & 35,380 & 40,506 & 8.12 & 6.0 & 1.8 & 97.36 & 7.0 \\
\hline Bulgaria & 11,370 & 2,580 & 6.56 & 0.4 & 7.5 & 71.10 & 5.7 \\
\hline Czech Rep. & 22,890 & 9,693 & 14.26 & 1.1 & 3.3 & 73.50 & 4.4 \\
\hline Denmark & 37,530 & 42,918 & 15.57 & 1.8 & 2.7 & 86.68 & 3.3 \\
\hline Germany & 35,950 & 37,402 & 13.52 & 27.4 & 2.2 & 73.64 & 7.5 \\
\hline Estonia & 19,320 & 8,016 & 10.50 & 0.2 & 3.7 & 69.46 & 5.5 \\
\hline Ireland & 35,710 & 42,008 & 26.49 & 2.6 & 5.6 & 61.34 & 6.0 \\
\hline Greece & 28,300 & 27,197 & 9.96 & 0.5 & 8.5 & 61.00 & 7.7 \\
\hline Spain & 30,830 & 23,503 & 5.16 & 4.4 & 4.3 & 77.12 & 11.3 \\
\hline France & 33,280 & 31,727 & 20.24 & 11.4 & 3.0 & 77.36 & 7.4 \\
\hline Italy & 30,800 & 29,790 & 6.68 & 11.5 & 3.8 & 68.08 & 6.7 \\
\hline Cyprus & 24,980 & 24,331 & 31.77 & 0.0 & 4.3 & 69.90 & 3.7 \\
\hline Latvia & 16,010 & 5,882 & 7.14 & 0.1 & 7.7 & 68.12 & 7.5 \\
\hline Lithuania & 17,170 & 5,665 & 11.42 & 0.4 & 7.7 & 66.96 & 5.8 \\
\hline Luxembourg & 52,770 & 47,012 & 6.61 & 0.2 & 1.8 & 82.44 & 5.1 \\
\hline Hungary & 18,210 & 8,146 & 24.15 & 1.2 & 4.5 & 67.50 & 7.8 \\
\hline Malta & 20,580 & 17,549 & 50.16 & 0.1 & 1.7 & 94.26 & 6.0 \\
\hline Netherlands & 40,620 & 38,575 & 22.21 & 7.1 & 2.7 & 81.82 & 2.8 \\
\hline Austria & 37,360 & 35,605 & 10.93 & 2.6 & 5.6 & 67.16 & 3.8 \\
\hline Poland & 16,710 & 8,593 & 5.24 & 1.7 & 14.7 & 61.32 & 7.1 \\
\hline Portugal & 22,330 & 16,699 & 8.38 & 0.7 & 11.5 & 59.46 & 7.6 \\
\hline Romania & 13,380 & 4,217 & 7.24 & 0.7 & 28.7 & 54.24 & 5.8 \\
\hline Slovenia & 27,160 & 15,811 & 6.10 & 0.5 & 10.2 & 48.60 & 4.4 \\
\hline Slovakia & 21,460 & 6,686 & 5.27 & 0.5 & 4.0 & 56.56 & 9.5 \\
\hline Finland & 35,940 & 34,842 & 21.23 & 2.3 & 4.5 & 48.60 & 6.4 \\
\hline Sweden & 37,780 & 34,001 & 15.84 & 3.8 & 2.2 & 84.54 & 6.2 \\
\hline $\begin{array}{l}\text { United } \\
\text { Kingdom }\end{array}$ & 36,240 & 41,731 & 19.26 & 10.8 & 1.4 & 89.94 & 5.6 \\
\hline
\end{tabular}

Source: own based on World Development Indicators (World Bank), EUROSTAT and Statistics Iceland databases 


\section{Ekonomie}

Tab. 3: Final ranks given to Member States and their roles, 2008

\begin{tabular}{|c|c|c|c|c|c|}
\hline \multirow{2}{*}{ Member State } & \multicolumn{4}{|c|}{ Ranks } & \multirow{2}{*}{$\begin{array}{c}\text { Role in the European } \\
\text { World-System }\end{array}$} \\
\hline & MULTIMOORA & TOPSIS & $\Sigma$ & Final & \\
\hline Austria & 10 & 14 & 24 & 12 & Semi-Periphery \\
\hline Belgium & 5 & 7 & 12 & 6 & Core \\
\hline Bulgaria & 25 & 22 & 47 & 25 & Periphery \\
\hline Cyprus & 23 & 12 & 35 & 17 & Semi-Periphery \\
\hline Czech Republic & 13 & 15 & 28 & 15 & Semi-Periphery \\
\hline Denmark & 8 & 9 & 17 & 8 & Core \\
\hline Estonia & 21 & 18 & 39 & 19 & Periphery \\
\hline Finland & 11 & 13 & 24 & 11 & Semi-Periphery \\
\hline France & 3 & 3 & 6 & 3 & Core \\
\hline Germany & 1 & 1 & 2 & 1 & Core \\
\hline Greece & 17 & 20 & 37 & 18 & Semi-Periphery \\
\hline Hungary & 15 & 17 & 32 & 16 & Semi-Periphery \\
\hline Ireland & 9 & 10 & 19 & 9 & Core \\
\hline Italy & 7 & 5 & 12 & 5 & Core \\
\hline Latvia & 27 & 24 & 51 & 26 & Periphery \\
\hline Lithuania & 22 & 21 & 43 & 23 & Periphery \\
\hline Luxembourg & 14 & 11 & 25 & 13 & Semi-Periphery \\
\hline Malta & 16 & 6 & 22 & 10 & Semi-Periphery \\
\hline Netherlands & 4 & 4 & 8 & 4 & Core \\
\hline Poland & 20 & 26 & 46 & 24 & Periphery \\
\hline Portugal & 18 & 25 & 43 & 22 & Periphery \\
\hline Romania & 26 & 27 & 53 & 27 & Periphery \\
\hline Slovakia & 24 & 19 & 43 & 21 & Periphery \\
\hline Slovenia & 19 & 23 & 42 & 20 & Periphery \\
\hline Spain & 12 & 16 & 28 & 14 & Semi-Periphery \\
\hline Sweden & 6 & 8 & 14 & 7 & Core \\
\hline United Kingdom & 2 & 2 & 4 & 2 & Core \\
\hline
\end{tabular}

Source: designed by the author

Finland, Malta, Spain, Czech Republic, Hungary, Greece and Cyprus to be classified as semi peripheral states. On the other hand, Portugal, Slovenia, Estonia, Lithuania, Poland, Slovakia, Bulgaria, Latvia and Romania should be considered as periphery of the European worldsystem. As mentioned before, semi-periphery and periphery of the European world-system depend to semi-periphery of the global worldsystem. Since the analysis is based on data of 2008 , it is necessary to further develop such investigations. There may be some dynamics in the European world-system, because certain states (e.g. Greece) experienced economic downturn while others (e.g. Poland) managed to relatively improve their positions.

\section{Conclusion}

Theoreticians of the world-system approach defined three positions of the participants: core, periphery and semi-periphery. Core states are described as producing and exporting 
high-technology production, employing highwage labour thus dominating politically and economically in the world-system. Peripheral states are not developed economically thus mainly raw materials comprises the largest part of exports. Semi-peripheral countries possess the intermediary position. World-systems are dynamic structures; hence participants can experience either descents or ascents.

A new conceptual model for identification of roles in the European world-system was proposed. It consists of three main parts: 1) system of indicators; 2) application of multicriteria evaluation methods; and 3) final ranking of the states thus identifying their roles. The system of indicators was defined according to world-system approach. Suggested system of indicators encompasses the following indicators: GNI per capita, average annual earnings, high-technology exports, share of extra-EU exports, employment in agriculture, share of urban population, rate of unemployment. MULTIMOORA method and TOPSIS were applied. Summarized ranks suggest that a group of states, namely Germany, United Kingdom, the Netherlands, Italy, Belgium, Denmark and Sweden, depends to the core of the European world-system. The new European Union Member States Romania and Bulgaria, three Baltic States (Estonia, Latvia and Lithuania) with Poland, Portugal, Slovakia and Slovenia can be considered as peripheral states in the European world-system. The new strategy Europe 2020 (European Commission, 2010; European Council, 2010) needs to be aimed at providing significant support for these states.

The ranks obtained by application of MULTIMOORA and TOPSIS methods reflect relative positions of the European Union Member States according to their level of economic and technological development. Since these ranks are obtained by summarizing a system of indicators, the findings of this study will enable to test the hypothesis about innovation impact on roles of certain states in the worldsystem. Correlated with results from various competitiveness studies (Porter \& Schwab, 2008; Pro-Inno Europe, 2009), the results of this study would lead to more robust and complex analysis. Furthermore, the model for evaluation of economic and technological development can be modified by changing objectives and multicriteria evaluation methods.

\section{References}

Ahmed, R. R., Vveinhardt, J., \& Streimikiene, D. (2018). The direct and indirect impact of pharmaceutical industry in economic expansion and job creation: evidence from bootstrapping and normal theory methods. Amfiteatru Economic, 20(48), 454-469. https://dx.doi.org/10.24818/EA/2018/48/454.

Baležentis, T., Štreimikienè, D., Melnikienè, R., \& Yu, Z. (2017). Non-parametric analysis of yield risk in Lithuanian crop farming. Journal of Business Economics and Management, 18(3), 521-536. https://dx.doi.org/10.3846/16111699. 2017.1322633.

Belser, P., de Cock, M., \& Mehran, F. (2005). ILO Minimum Estimate of Forced Labour in the World. Geneva: International Labour Office.

Bosma, N., \& Levie, J. (2010). Global Entrepreneurship Monitor. 2009 Executive Report. Global Entrepreneurship Research Association. Retrieved December 10, 2017, from https://www.gemconsortium.org/report.

Brauers, W. K. (2002). The multiplicative representation for multiple objectives optimization with an application for arms procurement. Naval Research Logistics, 49(4), 327-340. https://dx.doi.org/10.1002/nav.10014.

Brauers, W. K. (2004). Optimization Methods fora Stakeholder Society, a Revolution in Economic Thinking by Multi-Objective Optimization. Boston: Kluwer Academic Publishers.

Brauers, W. K. (2007). What is meant by normalization in decision making? International Journal of Management and Decision Making, 8(5/6), 445-460. https://dx.doi.org/10.1504/ IJMDM.2007.013411.

Brauers, W. K. M., \& Ginevičius, R. (2009). Robustness in Regional Development Studies. The Case of Lithuania. Journal of Business Economics and Management, 10(2), 121-140. https://dx.doi.org/10.3846/16111699.2009.10.121-140.

Brauers, W. K. M., \& Ginevičius, R. (2010). The economy of the Belgian regions tested with MULTIMOORA. Journal of Business Economics and Management, 11(2), 173-209. https://dx.doi.org/10.3846/jbem.2010.09.

Brauers, W. K. M., \& Zavadskas, E. K. (2006). The MOORA method and its application to privatization in a transition economy. Control and Cybernetics, 35(2), 445-469.

Brauers, W. K. M., \& Zavadskas, E. K. (2010). Project management by MULTIMOORA as an instrument for transition economies. 
Technological and Economic Development of Economy, 16(1), 5-24. https://dx.doi. org/10.3846/tede.2010.01.

Brauers, W. K. M., Ginevičius, R., Zavadskas, E. K., \& Antuchevičienè, J. (2007). The European Union in a transition economy. Transformations in Business \& Economics, 6(2), 21-37.

Brauers, W. K., \& Zavadskas, E. K. (2009). Robustness of the multi-objective MOORA method with a test for the facilities sector. Technological and Economic Development of Economy, 15(2), 352-375. https://dx.doi. org/10.3846/1392-8619.2009.15.352-375.

Chase-Dunn, C. K. (1979). Comparative Research on World-System Characteristics. International Studies Quarterly, 23(4), 601-623. https://dx.doi.org/10.2307/2600333.

Chen, J., Wang, J., Baležentis, T., Zagurskaitè, F., Streimikiene, D., \& Makutènienè, D. (2018). Multicriteria Approach towards the Sustainable Selection of a Teahouse Location with Sensitivity Analysis. Sustainability, 10(8), 2926. https://doi.org/10.3390/su10082926.

Churchman, C. W., Ackoff, R. L., \& Arnoff, E. L. (1957). Introduction to Operations Research. New York: Wiley.

De Arriba Bueno, R. (2010). Assessing Economic Transition in Eastern Europe after Twenty Years. Transformations in Business \& Economics, 9(2), 42-63.

European Commission. (2010). Europe 2020: A Strategy for Smart, Sustainable and Inclusive Growth. Retrieved December 10, 2017, from https://europa.eu/capacity4dev/ es4y/document/europe-2020-strategy-smartsustainable-and-inclusive-growth.

European Council. (2010). European Council 17 June 2010 Conclusions. EUCO 13/10 CO EUR 9 CONCL 2.

Fagerberg, J., \& Srholec, M. (2008). National innovation systems, capabilities and economic development. Research Policy, 37(9), 1417-1435. https://doi.org/10.1016/j. respol.2008.06.003.

Huggins, R., \& Izushi, H. (2009). Regional Benchmarking in a Global Context: Knowledge, Competitiveness, and Economic Development. Economic Development Quarterly, 23(4), 275-293. https://dx.doi. org/10.1177/0891242409347896.

Hwang, C. L., \& Yoon, K. (1981). Multiple Attribute Decision Making Methods and Applications. Berlin: Springer Verlag.
Yan, Q., Yin, J., Baležentis, T., Makutènienè, D., \& Štreimikienè, D. (2017). Energy-related GHG emission in agriculture of the European countries: An application of the Generalized Divisia Index. Journal of Cleaner Production, 164, 686-694. https://doi.org/10.1016/j. jclepro.2017.07.010.

Kettani, O., Aouni, B., \& Martel, J. M. (2004). The double role of the weight factor in the goal programming model. Computers \& Operations Research, 31(11), 1833-1845. https://doi. org/10.1016/S0305-0548(03)00142-4.

Korpysa, J. (2010). Unemployment as a Main Determinant of Entrepreneurship. Transformations in Business \& Economics, 9(1), 109-123.

Lane, D. (2006). From state socialism to capitalism: The role of class and the world system. Communist and Post-Communist Studies, 39(2), 135-152. https://dx.doi.org/ 10.1016/j.postcomstud.2006.03.003.

Li, T., Yu, W., Baležentis, T., Zhu, J., \& Ji, Y. (2017). Rural demographic change, rising wages and the restructuring of Chinese agriculture. China Agricultural Economic Review, 9(4), 478-503. https://dx.doi.org/10.1108/CAER-022016-0025.

Liagouras, G. (2010). What can we learn from the failures of technology and innovation policies in the European periphery? European Urban and Regional Studies, 17(3), 331-349. https://doi.org/10.1177/0969776409356214.

Ma, J., Balezentis, T., Zhao, Z., \& Fang, C. (2017). One Belt One Road (OBOR) initiative in Central Asia: The study of OBOR on China and Central Asia agricultural trade. Transformation in Business \& Economics, 16(3), 41-55

Maloney, W. (2004). Informality Revisited. World Development, 32(7), 1159-1178. https://dx.doi.org/10.1016/j.worlddev.2004.01.008.

Montgomery, M. R. (2008). The Urban Transformation of the Developing World. Science, 319(5864), 761-764. https://doi. org/10.1126/science. 1153012 .

Moore, J. W. (2003). The Modern World-System as environmental history? Ecology and the rise of capitalism. Theory and Society, 32(3), 307-377. https://doi. org/10.1023/A:1024404620759.

Porter, M. E., \& Schwab, K. (2008). The Global Competitiveness Report 2008-2009. Geneva: World Economic Forum.

Pro-Inno Europe. (2009). European Innovation Scoreboard 2008: Comparative 
Analysis of Innovation Performance. Retrieved December 10, 2017, from https://www.eas.ee/images/doc/sihtasutusest/ uuringud/innovatsioon/european_innovation_ scoreboard_2009.pdf.

Ravallion, M. (2010). The Developing World's Bulging (but Vulnerable) Middle Class. World Development, 34(4), 445-454. https://doi.org/10.1016/j.worlddev.2009.11.007.

Sabadie, J. A., \& Johansen, J. (2010). How Do National Economic Competitiveness Indices View Human Capital? European Journal of Education, 45(2), 236-258. https://dx.org/10.1111/j.1465-3435.2010.01427.x.

Schumpeter, J. (1939). Business Cycles. New York: McGraw-Hill.

Shannon, T. (1996). An Introduction to the World-System Perspective (2nd ed.). New York: Routledge.

Snyder, D., \& Kick, E. L. (1979). Structural Position in the World System and Economic Growth, 1955-1970: A Multiple-Network Analysis of Transnational Interactions. American Journal of Sociology, 84(5), 1096-1126. https://doi.org/10.1086/226902.

Su, W., Liu, M., Zeng, S., Štreimikienè, D., Baležentis, T., \& Ališauskaitė-Šeškienè, I. (2018). Valuating renewable microgeneration technologies in Lithuanian households: A study on willingness to pay. Journal of Cleaner Production, 191, 318-329. https://dx.doi. org/10.1016/j.jclepro.2018.04.199.

Van Rossem, R. (1996). The World System paradigm as general Theory of Development: A Cross-National Test. American Sociological Review, 61(3), 508-527. https://doi.org/10.2307/2096362.

Wallerstein, I. (1974). The Modern WorldSystem. Orlando: Academic Press.
Wallerstein, I. (1979). The Capitalist World Economy. Cambridge: Cambridge University Press.

Wallerstein, I. (2004). World-Systems Analysis. In World System History. Encyclopedia of Life Support Systems. Oxford: UNESCO, Eolss Publishers.

Zeng, S., Mu, Z., \& Baležentis, T. (2018). A novel aggregation method for Pythagorean fuzzy multiple attribute group decision making. International Journal of Intelligent Systems, 33(3), 573-585. https://dx.doi.org/10.1002/int.21953.

Zeng, S. Z., \& Xiao, Y. (2018). A method based on TOPSIS and distance measures for hesitant fuzzy multiple attribute decision making. Technological and Economic Development of Economy, 24(3), 969-983. https://doi.org/10.38 46/20294913.2016.1216472.

Zhou, J., Su, W., Baležentis, T., \& Streimikiene, D. (2018). Multiple Criteria Group Decision-Making Considering Symmetry with Regards to the Positive and Negative Ideal Solutions via the Pythagorean Normal Cloud Model for Application to Economic Decisions. Symmetry, 10(5), 140. https://dx.doi. org/10.3390/sym10050140.

Zhu, N., Stjepcevic, J., Baležentis, T., Yu, Z., \& Wang, B. (2017). How does corporate social responsibility impact banking efficiency: a case in China. E\&M Ekonomie a Management, 20(4), 70-87. https://dx.doi.org/10.15240/ tul/001/2017-4-006.

Changxing Li, PhD

Shanghai University of Finance and Economics School of Economics China Changxing_li@126.com 


\section{Abstract}

\section{EVALUATION OF THE FINANCIAL AND ECONOMIC DEVELOPMENT OF THE EUROPEAN UNION MEMBER STATES ON BASIS OF MULTIPLE INDICATORS CHANGED TO MULTIPLE OBJECTIVES}

\section{Changxing Li}

Innovation has received more and more attention in the European Union since adoption of the Lisbon Strategy in 2000. In 2010 the European Commission 2010; European Council adopted a new strategy, Europe 2020, which stressed again the importance of innovations. Therefore it is important to evaluate the current level of the European Union Member States' technological and economic development as well as its innovations impact on it. Innovation impact on economic development was analyzed by correlating various composite indices with GDP per capita indicator.

A new conceptual model for the European Union Member States' technological and economic development according to the world-system approach is proposed in this article. The world-system approach describes structure, relations and dynamics of international systems encompassing separate entities such as states. Three main roles of the states can be defined: core, semiperiphery and periphery. Core states are the most technologically and economically developed ones and accumulate capital from peripheral states. The model consists of system of indicators, application of multi-criteria evaluation methods and summarized ranking. The system of indicators covers indicators describing technological, economic and social situation in the European Union treated as objectives. MULTIMOORA and TOPSIS methods were used together in order to improve robustness of the analysis. Summarized ranks resemble level of technological and economic development of certain European Union Member States and thus their roles in the European worldsystem. There were three groups of Member States defined, representing core, semi-periphery and periphery of the European world-system. These ranks can be used in further studies instead of single indicators representing economic development (e.g. GDP per capita). In addition, some theoretical issues regarding multi-criteria evaluation methods are discussed in the paper.

Key Words: Economic development, MOORA, MULTIMOORA, TOPSIS, world-system, European Union, strategic management, innovation.

JEL Classification: 010, O31, O32, G10.

DOI: 10.15240/tul/001/2018-4-002 